\title{
Chronic graft-versus-host disease: clinical presentation of multiple lesions of lichenoid and atrophic pattern*
}

\author{
Doença enxerto contra hospedeiro crônica: apresentação clínica com \\ inúmeras lesões de padrão liquenóide e de caráter atrófico
}

\author{
Luiza Vasconcelos ${ }^{1}$ \\ Ana Gabriela Salvio ${ }^{3}$ \\ Silvio Alencar Marques ${ }^{6}$
}

\author{
Érica Cristina Vieira ${ }^{1}$ \\ Mair Pedro de Souza ${ }^{4}$
}

\author{
Eliana Maria Minicucci ${ }^{2}$ \\ Mariangela Esther Alencar Marques ${ }^{5}$
}

\begin{abstract}
Graft-versus-host disease is observed mainly in recipients of hematopoietic cell transplantation and is expressed by cutaneous or systemic signals and symptoms. Graft-versus-host disease is clinically classified as acute or chronic. Chronic Graft-versus-host disease occurs in up to 70\% of hematopoietic cell transplanted patients and its clinical manifestations have important impact on morbidity and quality of life. The authors report an expressive cutaneous, oral and adnexal involvement in a patient with chronic Graft-versus-host disease with multiple lesions of lichenoid and atrophic pattern.

Keywords: Bone marrow transplantation; Clinical evolution; Graft vs host disease; Lichen sclerosus et atrophicus

Resumo: Doença enxerto contra hospedeiro é observada principalmente em pacientes transplantados de células de origem hematopoiéticas e se expressa por sinais e sintomas cutâneos ou sistêmicos. Clinicamente, a Doença enxerto contra hospedeiro é classificada em aguda ou crônica. As do tipo crônico ocorrem em até 70 \% dos pacientes e suas manifestações têm impacto importante na morbidade e na qualidade de vida. Os autores relatam caso com extenso comprometimento cutâneo, oral e de anexos cutâneos em paciente com Doença enxerto contra hospedeiro crônica expressa por inúmeras lesões de padrão liquenóide e de atrofia cutânea.

Palavras-chave: Doença enxerto-hospedeiro; Evolução clínica; Líquen escleroso e atrófico; Transplante de medula óssea
\end{abstract}

\section{INTRODUCTION}

The graft-versus-host disease (GVHD) is an immune-mediated syndrome expressed by cutaneous or cutaneous / systemic signals and symptoms, mainly in recipients of allogeneic stem cells or bone marrow transplantation, but also following blood transfusion and solid organ transplantation. ${ }^{1-3}$ Graft-versushost disease is induced and maintained by mature

donor T cells, which clonally expand in an antigenspecific manner after the recognition of non-self HLA expressed on the surface of the host's nucleated cells, thus increasing HLA incompatibility between donor and recipient. ${ }^{1-3}$ Graft-versus-host disease is clinically classified as acute or chronic. Acute GVHD (aGVHD) is historically defined as the onset of signs and symp-

Received on 15.09.2012.

Approved by the Advisory Board and accepted for publication on 15.10.2012.

Work performed at the Department of Dermatology and Radiotherapy. Botucatu Medical School, São Paulo State University "Júlio de Mesquita Filho" (FMB-UNESP) Botucatu (SP), Brazil.

Conflict of interest: None

Financial funding: None

MD - Residency Program - - Department of Dermatology and Radiotherapy. Botucatu Medical School, São Paulo State University "Júlio de Mesquita Filho" (FMB-UNESP) - Botucatu (SP), Brasil.

DDS, PhD - Stomatologist - Department of Dermatology and Radiotherapy. Botucatu Medical School, São Paulo State University "Júlio de Mesquita Filho" (FMB-UNESP) - Botucatu (SP), Brazil.

MD, PhD - Dermatologist - Amaral Carvalho Hospital - Jaú (SP) - Brazil

MD - Hematologist - Amaral Carvalho Hospital - Jaú (SP) - Brazil

MD, PhD - Associate Professor - Department of Pathology. Botucatu Medical School, São Paulo State University "Júlio de Mesquita Filho" (FMB-UNESP) Botucatu (SP), Brazil.

MD, PhD - Full Professor - Department of Dermatology and Radiotherapy. Botucatu Medical School, São Paulo State University "Júlio de Mesquita Filho" (FMB-UNESP) - Botucatu (SP), Brazil. 
toms within 100 days of transplant, and chronic GVHD (cGVHD) will appear after that period. ${ }^{1}$ However, recent transplant protocols, with less aggressive conditioning and new immune modulating strategies have altered the classification; therefore, the aGVHD category includes the classic aGVHD occurring within 100 days after transplant and the persistent, recurrent or late aGVHD. ${ }^{4}$ Chronic GVHD includes the classic cGVHD occurring any time after transplant and an overlap syndrome in which features of cGVHD and aGVHD appear together. ${ }^{4}$ Chronic GVHD occurs in up to $70 \%$ of hematopoietic cell transplanted patients. ${ }^{2,3}$ Dermatologists and stomatologists must play an active role in the management and treatment of patients with GVHD, as oral and cutaneous lesions have severe impact on morbidity and quality of life.

We report a clinical case of cGVHD with expressive cutaneous, oral and adnexal involvement occurring despite immunosuppressive therapy, presenting with numerous lichenoid and atrophic lesions.

\section{CASE REPORT}

A 52-year-old male patient presented with a history of an allogeneic bone-marrow transplant (matched sibling donor) performed in a reference Hospital, due to acute myeloid leukemia one year before. A conditioning regimen had been followed with oral busulfan and fludarabine phosphate and he was immunosuppressed from day 2 pre-transplant with cyclosporine, initial dose of $3 \mathrm{mg} / \mathrm{kg}$ and $7 \mathrm{mg} / \mathrm{kg}$ after the $21^{\text {th }}$ day post-transplant, sustained for 241 days plus tacrolimus and mycophenolate mofetil for seven and 45 days respectively. The patient denied acute GVHD and his clinical follow-up was unremarkable until six months post-transplant, when oral and skin lesions of chronic GVHD appeared. Since then the patient has been treated with prednisone up to $1 \mathrm{mg} / \mathrm{kg} /$ day with partial remission of the clinical picture. The initial skin lesions were described as erythematous and pruriginous papules, starting on the trunk with progressive spreading and oral lesions similar to lichen planus, with ulcers on the lower lip causing restriction to mouth opening.

Examination showed diffuse spotted hyper and hypopigmented skin, multiple lichenoid and atrophic lesions plus almost complete scarring alopecia, acral edema and erythema plus onychodistrophia of the 20 nails (Figures 1-4). Buccal examination showed shallow ulcers on the buccal mucosa and tongue, periodontal disease, salivary gland hypofunction, depapillated tongue and decreased taste. No pulmonary, gastrointestinal or renal involvement was detected. Histology of skin lesions showed discrete hyperkeratotic and atrophic epidermis with vacuolar interface dermatitis and scattered apoptosis of keratinocytes plus superficial sclerosis, vascular proliferation and mild lymphocytic infiltrate, suggestive of late evolution of lichenoid lesions (Figures 5 and 6).

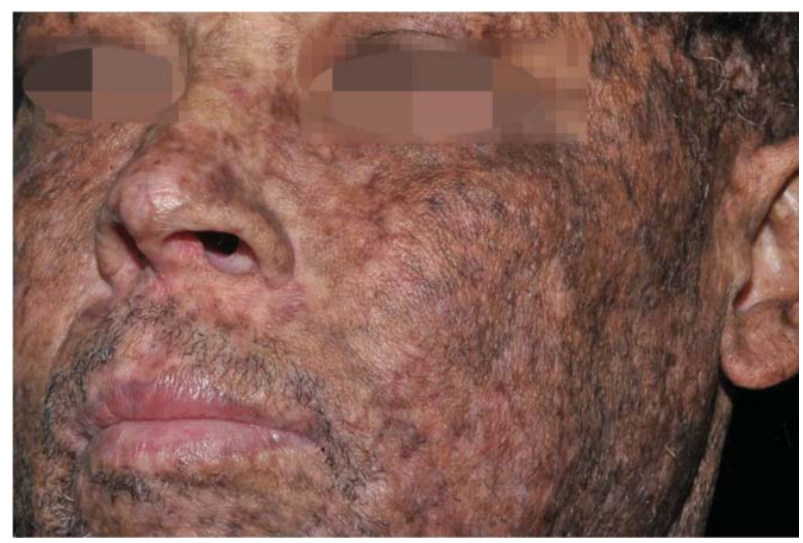

FIGURE 1: Graft-versus-host disease: spotted hyper and hypopigmented skin on the face
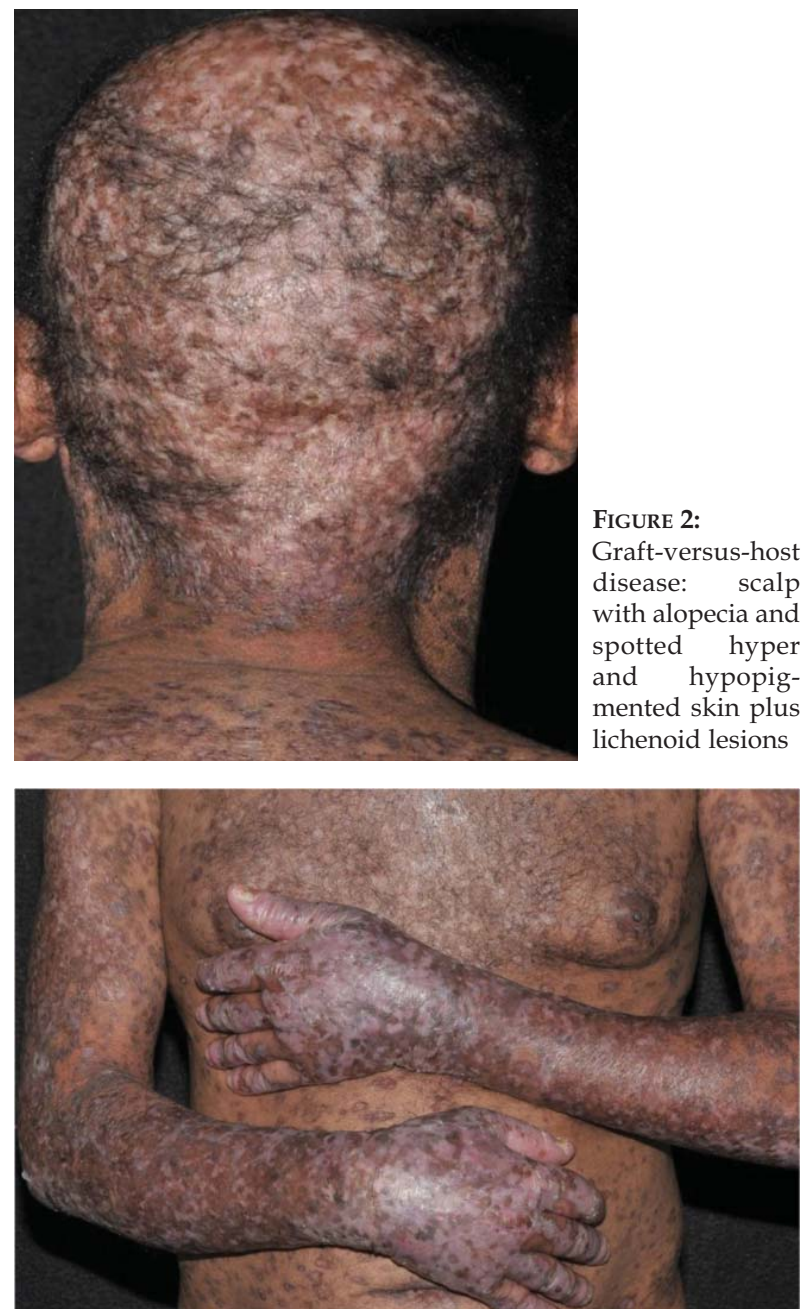

FiguRE 3: Graft-versus-host disease: lichenoid lesions, edema and erythema on the hands with associated onychodistrophia 


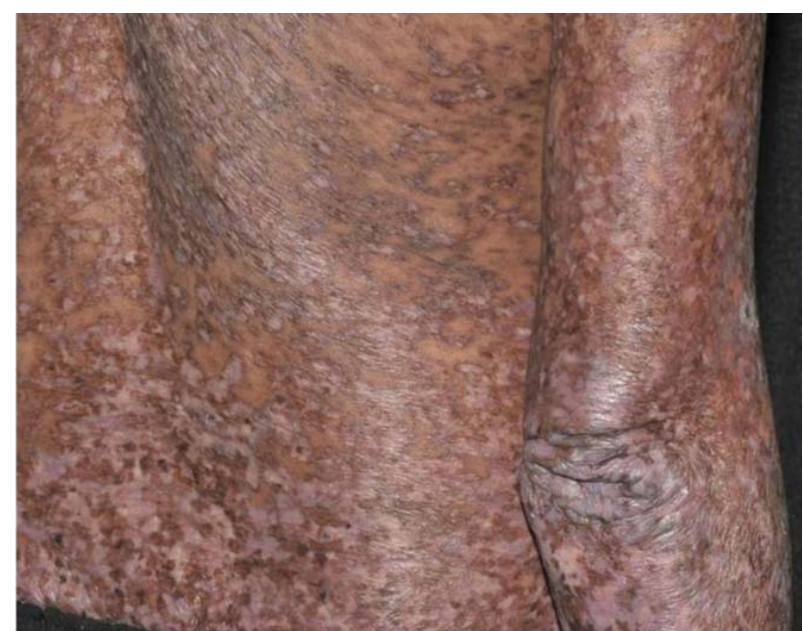

FIGURE 4: Graft-versus-host disease: more evident lichenoid and atrophic lesions on the back

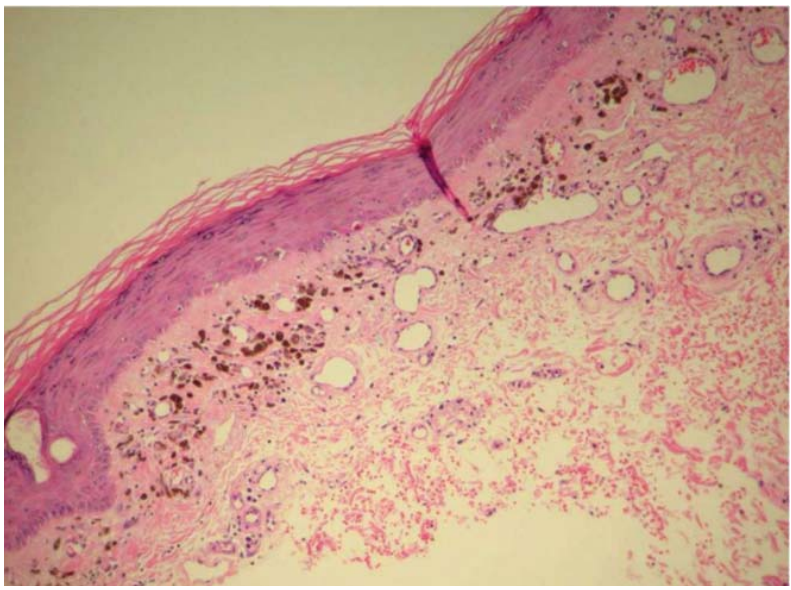

FIGURE 5: Graft-versus-host disease: discrete hyperkeratotic and atrophic epidermis plus vascular proliferation and mild lymphocytic infiltrate on the papillary dermis

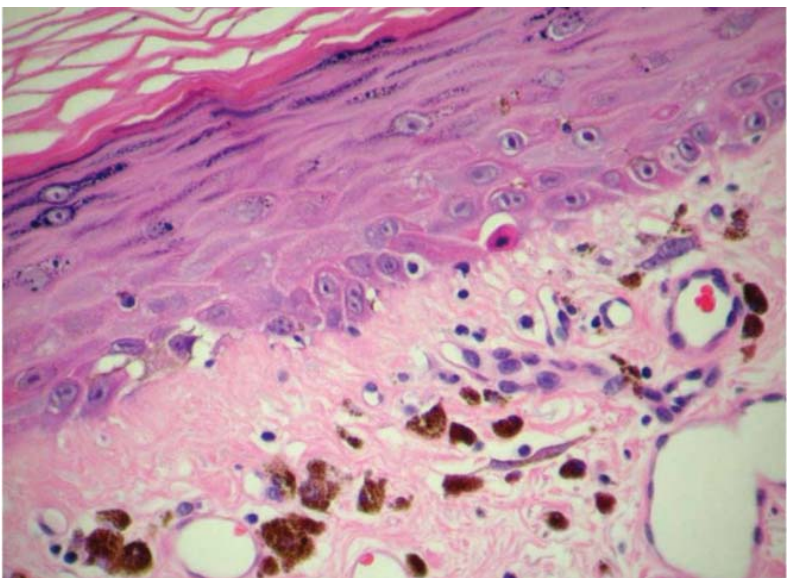

FIGURE 6: Graft-versus-host disease: high-power view shows hyperkeratotic and atrophic epidermis, vacuolar changes, apoptotic cell, discrete lymphocytic infiltration and incontinent melanin in the papillary dermis

\section{DISCUSSION}

Chronic GVHD is a major complication of allogeneic bone marrow and peripheral blood stem cell transplantation. The main risk factors include previous aGVHD, advanced recipient age, female donor to male recipient, transplant in patient with chronic myelogenous leukemia, previous splenectomy, second allogeneic transplant and a high degree of HLA mismatching. ${ }^{3}$ Chronic GVHD has an important impact on the survival and quality of life of transplanted patients. The skin is the most commonly involved organ, followed by the oral mucosa, liver, eye and GI tract, but virtually all organs or systems may be involved. ${ }^{3-6}$ Skin lesions in cGVHD are initially subtle with xerosis, follicular hyperkeratosis or with a pityriasiform, psoriasiform and eczematous aspect. Later on, more classic lesions of lichenoid or sclerodermoid pattern appear. ${ }^{1,5}$ Sclerotic skin changes are a prominent feature and a major source of morbidity. Dermal fibrosis may involve all layers of the skin with loss of subcutaneous tissue and may include the fascia and tendon. ${ }^{5}$ Our patient presents diffuse spotted hyperpigmentation and hypopigmentation associated with multiple lichenoid and small atrophic, scaly and hypopigmented plaques with histopathological presentation of atrophic epidermis and discrete lichenoid pattern. ${ }^{5}$ Buccal lesions manifest as gingivitis, mucositis, xerostomia and ulcers as observed. Involvement of oral mucosa is frequent and may be very relevant affecting the health and quality of life of patients. ${ }^{2,6}$ Despite the expressive mucocutaneous and adnexal involvement, no evidence of systemic disease has been detected in this particular patient so far, although this possibility cannot be ruled out during the patient's follow-up .

Systemic steroids are the appropriate first-line treatment for both acute and chronic GVHD, but if the patient is steroid refractory an alternative is the association of extracorporeal photopheresis, prednisone and sirolimus, or prednisone, sirolimus plus calcineurin inhibitors., ${ }^{3,-9}$ Localized, cutaneous GVHD may respond well to topical steroids or, alternatively, to tacrolimus and pimecrolimus. ${ }^{7}$ Although hematopoietic cell transplanted patients are counseled to avoid ultraviolet radiation due to possible GVHD flare or increased risk of skin cancer, psoralens plus ultraviolet A light (PUVA) or narrow band-ultraviolet $B$ phototherapy are the choice for the treatment of sclerotic cGVHD lesions. ${ }^{7-9}$ It is also important to have in mind that these patients have increased risk of secondary malignancies of the skin or mucosa including squamous cell carcinoma and melanoma, therefore dermatological screenings are recommended throughout life..$^{3,10}$ 


\section{REFERENCES}

1. Ferrara JL, Levine JE, Reddy P, Holler E. Graft-versus-host disease. Lancet. 2009;373:1550-61.

2. Hymes SR, Alousi AM, Cowen EW. Graft-versus-host disease. Part I. Pathogenesis and clinical manifestation of graft-versus-host disease. J Am Acad Dermatol. 2012;66: 515. e1-18.

3. Flowers ME, Inamoto Y, Carpenter PA, Lee SJ, Kiem HP, Petersdorf EW, et al. Comparative analysis of risk factors for acute graft-versus-host disease and for chronic graft-versus-host disease according to National Institute of Health consensus criteria. Blood. 2011:117:3214-9.

4. Filipovich AH, Weisdorf D, Pavletic S, Socie G, Wingard JR, Lee SF, et al. National Institutes of Health consensus development project on criteria for clinical trials in chronic graft-versus-host disease: I. Diagnosis and staging working group report. Biol Blood Marrow Transplant. 2005;11:945-55.

5. Hymes SR, Turner ML, Champlin RE, Couriel. DR. Cutaneous manifestations of chronic graft-versus-host disease. Biol Blood Marrow Transplant. 2006;12:1101-13.

6. Silva MM, Bouzas LFS, Filgueira AL. Tegumentary manifestations of graft-versushost disease in bone marrow transplantation recipients. An Bras Dermatol. 2005;80:69-80

7. Hymes SR, Alousi AM, Cowen. EW. Graft-versus-host disease: part II. Management of cutaneous graft-versus-host disease. J Am Acad Dermatol. 2012;66:535.e1-16.

8. Gruandmann-Kollmann M, Martin H, Ludwig R, Klein S, Boehncke WH, Hoelzer D, et al. Narrowband UV-B phototherapy in the treatment of cutaneous graft versus host disease. Transplantation 2002;74:1631-4.

9. Weitzing T, Sticherling M, Simon JC, Hegenbart U, Niederwieser D, Al-Ali HK. Medium dose long-wavelenght ultraviolet A (UVA-1) photherapy for the treatment of acute and chronic graft-versus-host disease. Bone Marrow Transplant. 2005;35:515-9.

10. Leisenring W, Friedman DL, Flowers ME, Schwartz JL, Deeg HJ. Nonmelanoma skin and mucosal cancers after hematopoietic cell transplantation. J Clin Oncol. 2006;24:1119-26

\author{
MAILING ADDRESS: \\ Silvio Alencar Marques \\ Departamento de Dermatologia e Radioterapia \\ Faculdade de Medicina de Botucatu \\ Distrito de Rubião Junior - S/N \\ 18618-970 - Botucatu - SP \\ Brazil \\ E-mail: smarques@fmb.unesp.br
}

How to cite this article: Vasconcelos L, Vieira EC, Minicucci EM, Salvio AG, Souza MP, Marques MEA, Marques SA. Chronic graft-versus-host disease: clinical presentation of multiple lesions of lichenoid and atrophic pattern. An Bras Dermatol. 2013;88(5)799-802. 